\title{
Freundschaft und Sexualität
}

\author{
Von \\ Dr. Siegfried Placzek \\ Nervenarzt in Berlin
}

Sechste, wenig veränderte Auflage

14.-16. T a usend

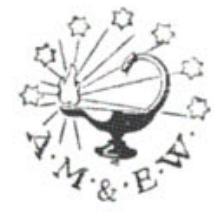

Berlin und Köln

A. Marcus \& E. Weber's Verlag 
Nachdrack verboten.

Alle Rechte, besonders das der Übersetzung in fremde Sprachen, von der Verlagsbucbhandlung vorbehalten.

Copyright 1920 by A. Marcus \& E. Weber's Verlag, Berlin und Köln. 


\section{Vorwort zur III. Auflage}

Uberraschend schnell, in knapp Jahresfrist, erlebt die Studie die III. Auflage. Ein vollgültiger Beweis für das anscheinend überaus rege Interesse, das dem tiefernsten Freundschaftsproblem und dessen vielfältig verästelten Wurzelfäden und Seitensprossen entgegengebracht wird, vielleicht auch eine bescheidene Anerkennung der Sachdarstellung, die ich dem Stoff zu geben versuchte. Wenn das Buch schon in der II. Auflage die doppelte Seitenzahl erreichte und auch in dieser Neuauflage an Umfang weiter wächst, so ist das nicht verwunderlich, da mit fortschreitendem, tieferem Eindringen in das Problem auch neue rätselvolle Fragen auftauchen und zur Beantwortung zwingen.

Möge dem Buch auch in seiner neuen Gestalt der gleiche Eirfolg beschieden sein wie bisher.

22. Dezember 1916.

\section{Dr. Placzek}

\section{Vorwort zur IV. Auflage}

Was ich der III. Auflage des Freundschaftsbuches als Schlußgeleitwunsch auf den Weg gab, hat sich voll, über Erwarten erfüllt. Der erhoffte neue Erfolg war ihr wieder beschieden. Immer stärker ist anscheinend das Interesse an dem lebenerfüllten Seelenproblem, das meine Studie behandelt, immer größer auch der Leserkreis. Das mußte anspornend wirken, immer tiefer die seelischen Zusammenhänge und Abhängigkeiten auszuschürfen, wie sie das Thema des Buches in Uberfülle bietet. So sind einzelne Kapitel wesentlich verändert worden, andere völlig neue hinzugekommen, wobei sich eine eingehende kritische Würdigung neuzeitlicher, allzu anspruchsvoll sich gebärdender, dogmatischer Lehrmeinungen, die komplizierte psychische Vorgänge angeblich restlos enträtseln wollen, nicht umgehen lieB.

Wenn dadurch das Buch auch inhaltlich sich änderte, in seiner Grundanlage und seinen Grundlehren ist es unverändert geblieben. Darum darf der Verfasser auch hoffen, daß dem Buche eine gleich günstige Aufnahme wie bisher beschieden sei.

6. August 1918. 